\title{
Seismic Capacity Assessment of Confined Brick Masonry Building: An Experimental Approach
}

\author{
Asfandyar Ahmed $\mathbb{D}^{1},{ }^{1}$ Imad Ahmad, ${ }^{1}$ Khan Shahzada, ${ }^{1}$ Muhammad Tayyab Naqash $\left(\mathbb{D},{ }^{2}\right.$ \\ Bashir Alam, ${ }^{1}$ Muhammad Fahad, ${ }^{1}$ and Sajjad Wali Khan ${ }^{1}$ \\ ${ }^{1}$ Department of Civil Engineering, University of Engineering \& Technology, Peshawar, Pakistan \\ ${ }^{2}$ Department of Civil Engineering, Islamic University of Madinah, Medina, Saudi Arabia
}

Correspondence should be addressed to Asfandyar Ahmed; engrasfandyar2009@gmail.com

Received 22 July 2017; Accepted 3 January 2018; Published 30 January 2018

Academic Editor: Giuseppe Brandonisio

Copyright (C) 2018 Asfandyar Ahmed et al. This is an open access article distributed under the Creative Commons Attribution License, which permits unrestricted use, distribution, and reproduction in any medium, provided the original work is properly cited.

\begin{abstract}
Brick masonry is widely used for building construction throughout the world. However, unreinforced brick masonry buildings performed poorly in the 2005 Kashmir earthquake, in Pakistan, resulting in a decline in the use of brick masonry. In order to investigate and quantify the performance of brick masonry against the seismic forces by confining it through typical stiffer, line elements (column and beams), a full-scaled room model of an area $3048 \times 3658 \mathrm{~mm}(10 \times 12 \mathrm{ft})$ and height of $3353 \mathrm{~mm}(11 \mathrm{ft})$ was constructed using confined brick masonry. The model was tested under quasistatic loading system. Crack pattern was noted at the end of each loading cycle. The response of the model was interpreted through a hysteresis curve, which was then idealized by a bilinear curve. A comparison of the results has been made with four different studies done on the similar model made of unreinforced brick masonry before and after retrofitting and unreinforced concrete block masonry before and after retrofitting previously tested at the same testing facility.
\end{abstract}

\section{Introduction}

One of the most important characteristics of masonry construction is its simplicity. Putting pieces of bricks/blocks/ stones on top of each other, with cohesion via mortar, is a simple, though adequate technique. In spite of its advantages, masonry has been replaced by concrete and steel as a structural material in many parts of the developed world, particularly in seismically active regions. The low tensile strength and ductility of the masonry seem to be the most important drawbacks to its implementation in building (Magenes 2006) [1].

The tensile strength and ductility of unconfined brick masonry are inferior to those of confined brick masonry. Moreover, masonry buildings were usually constructed based on rules of thumb obtained over many years of practice and/or empirical data from testing. Nowadays most of the building codes allow for elastic design of the structures with the result that such structures may be allowed to damage in an earthquake, but their collapse should be prevented, and the occupants of the building should be able to evacuate safely [2].

Confined masonry construction has been emerged as an alternative method as compared to unreinforced masonry and reinforced concrete (RC). The system is comprised of a masonry panel confined on all sides by horizontal and vertical $\mathrm{RC}$ elements with light reinforcement ratio. This method is considerably different as compared to the infill RC frame considering its construction methodology, as the masonry wall is constructed before the tie columns and beams [3]. In addition, the load transfer mechanism is different in this system under gravity and lateral loading. The confining elements (tie columns and beams) provide strength to the masonry panel and protect it from complete disintegration, especially under large lateral deformations [4].

The in-plane load transfer response of a confined masonry wall is very different from that of reinforced concrete infill frame [5].

An experimental study has been presented in this paper to evaluate the seismic performance of confined brick masonry 


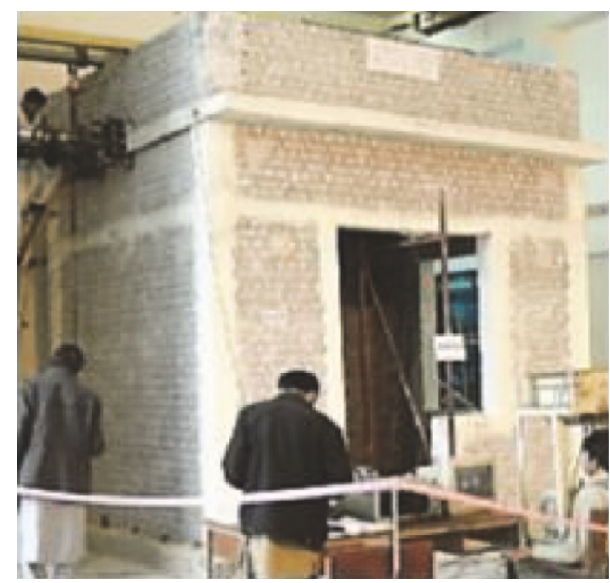

(a)

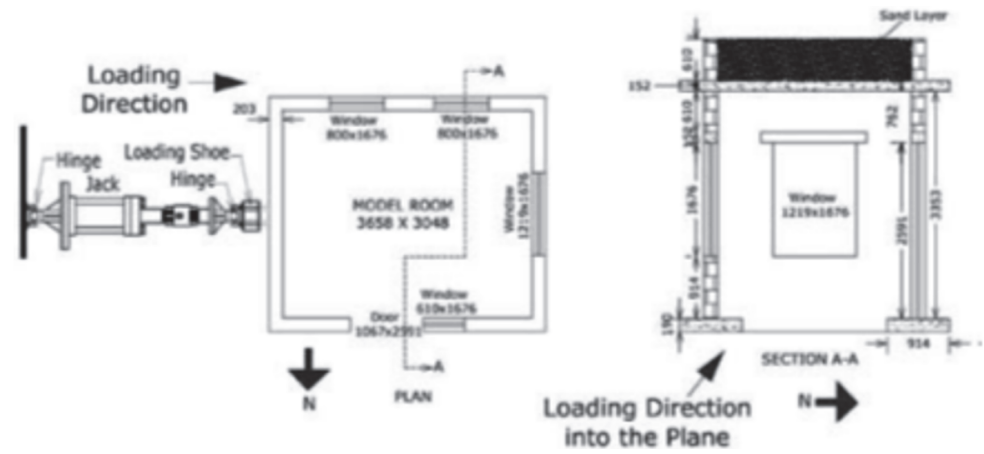

(b)

05

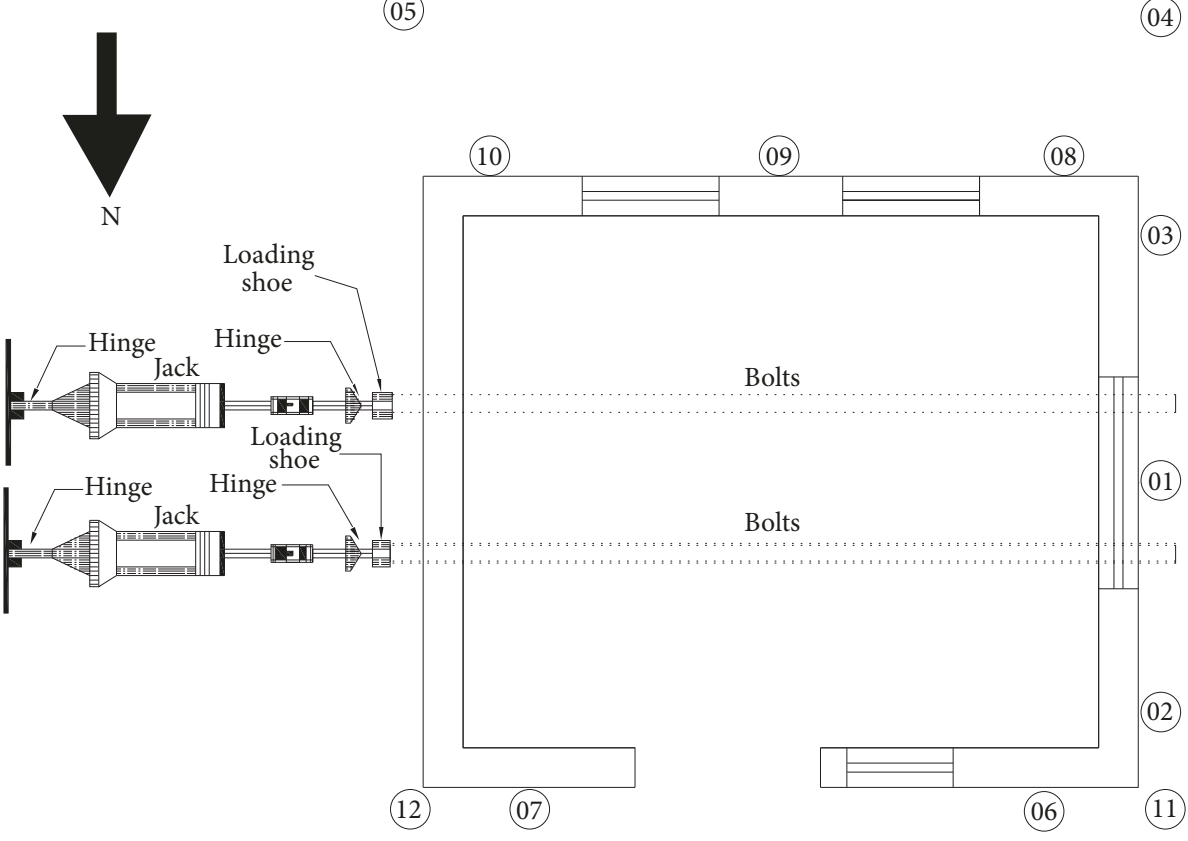

(c)

Figure 1: (a) A picture of the building model, (b) plan and elevation view details of full-scale building model, and (c) location of the hydraulic jacks in the tested building.

(CBM) buildings in the seismically active regions of Pakistan as well as in other similar regions around the world. Several experimental studies on unreinforced masonry (URM) buildings have been conducted worldwide. Studies on shear walls have been conducted by Epperson and Abrams [6], Abrams and Shah [7], Magenes and Calvi [8], Anthoine et al. [9], Manzouri et al. [10], Tomaževič et al. [11], Craig et al. [12], and Franklin et al. [13]. Similarly, Simsir et al. [14] worked out the out-of-plane behavior of walls.

However, none of the studies explained the behavior of local building materials and practices specific to CBM buildings in northern Pakistan. The main purpose of this study is to quantify the performance of CBM building that reflects the configuration of building most commonly built in northern parts of Pakistan.

\section{Experimental Program}

2.1. Design and Construction of Building Model. A full-scale model shown in Figure 1 was constructed for this study. The model resembles a typical interior room in a single story building in the local area. The model was constructed on the strong floor of the Earthquake Engineering Center at the University of Engineering and Technology Peshawar, Pakistan.

The interior dimensions of the room model were $3048 \times$ $3658 \mathrm{~mm}(10 \times 12 \mathrm{ft})$ and $229 \mathrm{~mm}$ (9 inches) thick; walls were made using 1: 5 cement-sand mortar with clay brick masonry in English bond pattern, which is the typical construction method in Pakistan. The brick dimensions were $216 \mathrm{~mm} \times$ $102 \mathrm{~mm} \times 70 \mathrm{~mm}$. To avoid the formation of continuous 


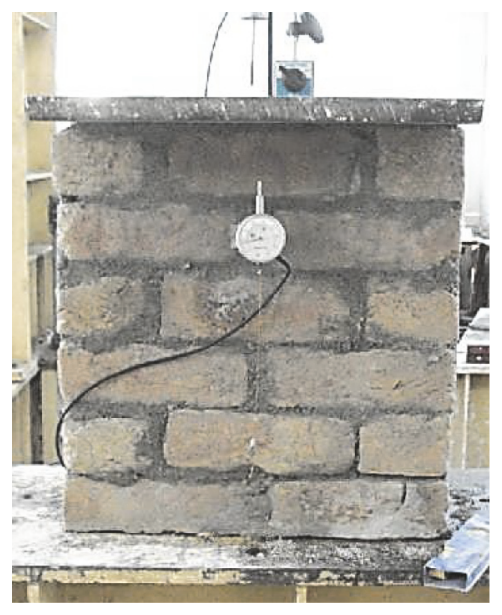

FIGURE 2: Compressive strength test of a masonry prism.

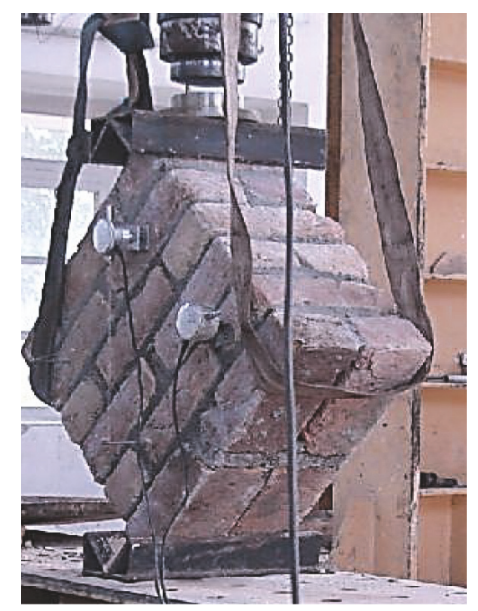

FIGURE 3: Diagonal compressive strength test of a masonry specimen.

vertical joints bricks were laid in a staggered manner (see Figure 1(a)). The in-plane walls that were connected to the foundation and the roof slab mainly resisted the lateral forces. The confining elements provided the lateral confinement to the walls. Connection of walls with confining columns was achieved through toothing. The model building was constructed over a $305 \mathrm{~mm}$ (12 inches) thick reinforced concrete (RC) pad that was connected to the strong floor via bolts. $76.2 \mathrm{~mm}(3 \mathrm{in})$ toothing was spared in every layer of masonry at the four corners and around each opening of the room which was later filled with $(1: 2: 4)$ concrete. The filling was done in 3 layers with sufficient rodding to achieve the compaction. Each confining tie column was reinforced with 4 \#4 (12 mm-dia) bars tied by \#3 (9.5 mm-dia) stirrups at $9^{\prime \prime}(229 \mathrm{~mm}) \mathrm{c} / \mathrm{c}$. Lintel beams having a size of $152 \mathrm{~mm}$ $\times 229 \mathrm{~mm}(6 \times 9$ in $)$ were casted over all the openings. The beam was reinforced with 2 \#4 (12 mm-dia) bars in tension and $2 \# 4$ (12 mm-dia) bars as hangers and was tied by \#3 (9.5 mm-dia) stirrups at $152 \mathrm{~mm}$ (6 in) c/c spacing. Reinforced concrete slab having a thickness of $152 \mathrm{~mm}$ (6 in) was casted over the model. The slab was reinforced in both directions with \#4 (12 mm-dia) bars spaced at $229 \mathrm{~mm}$ (9 in) center to center. $343 \mathrm{~mm}$ (13.5 in) thick masonry walls having a height of $762 \mathrm{~mm}$ ( $2.5 \mathrm{ft}$ ) were constructed over the slab that accounts for the dead load in vertical direction over the roof of the building from the adjacent parts of it. In order to take the effect of the roof treatment, a $381 \mathrm{~mm}$ (15 in) thick sand layer was spread over all the roof of the building. Lateral loading was applied through two hydraulic jacks that were fixed against the strong wall on the side of room model with no openings (see Figure 1(b)). To study the flange effect, a window was also provided in one of the out-of-plane walls.

Compressive strength and modulus of elasticity of masonry were determined through test conducted on masonry prisms, $457 \mathrm{~mm}$ long $\times 457 \mathrm{~mm}$ high $\times 229 \mathrm{~mm}$ thick (18 $\times 18 \times 9$ inches) according to ASTM C1314 [2012], as shown in Figure 2. Tensile strength was determined from diagonal compression test on masonry prisms that were also $457 \mathrm{~mm}$ long $\times 457 \mathrm{~mm}$ high $\times 229 \mathrm{~mm}$ thick $(18 \times 18 \times 9$ inches), as shown in Figure 3. The low diagonal strength of the masonry indicated the weak bond between the mortar and the brick unit.

ASTM C109/C109M [2013] was used to determine the compressive strength of mortar. The 1:5 cement-sand mortar used in this study was based on the local construction practice in Pakistan for solid brick masonry. Various material properties determined through tests are summarized in Table 1.

2.2. Test Setup and Testing Procedure. The lateral loading was applied on the full-scale room model through two hydraulic jacks that were attached to the slab on the east side of building. The capacity of each loading jack was $200 \mathrm{kN}$ (45 kips). This arrangement is shown in Figure 1. The model was fixed to the strong floor via posttensioning bolts.

In the push direction, bearing through the loading shoes was the means of applying the force to the building. For the pull direction, rods were placed above and below the slab starting from the out-of-plane east wall and ending at the outof-plane west wall. Bolts were fastened at both ends to fix the rods at their position. The loading arrangement is shown in Figure 1(c).

To measure displacements, 12 linear variable displacement transducers (LVDT) were used; the arrangement is presented in Figure 4. Gauge 01 was the control gauge, which was used to record the in-plane displacement at the middle center of the slab. Gauges $02-05$ were used to measure the twisting of the structure. The displacement at the top of the piers was measured with gauges $06-10$. Gauges 11 and 12 were used to determine the possible vertical displacement due to global rocking of the building.

The dead load stresses on the north wall (i.e., pier 01 and pier 02 according to Figure 4 ) and the south wall (i.e., pier 03 , pier 04 , and pier 05) were calculated as 0.14 and $0.12 \mathrm{MPa}$, respectively. The dead load values could be easily compared to material properties given in Table 1 .

The model was subjected to increasing reversed quasistatic loading cycles at the roof level with each cycle being repeated three times (see Figure 5). The test was performed 


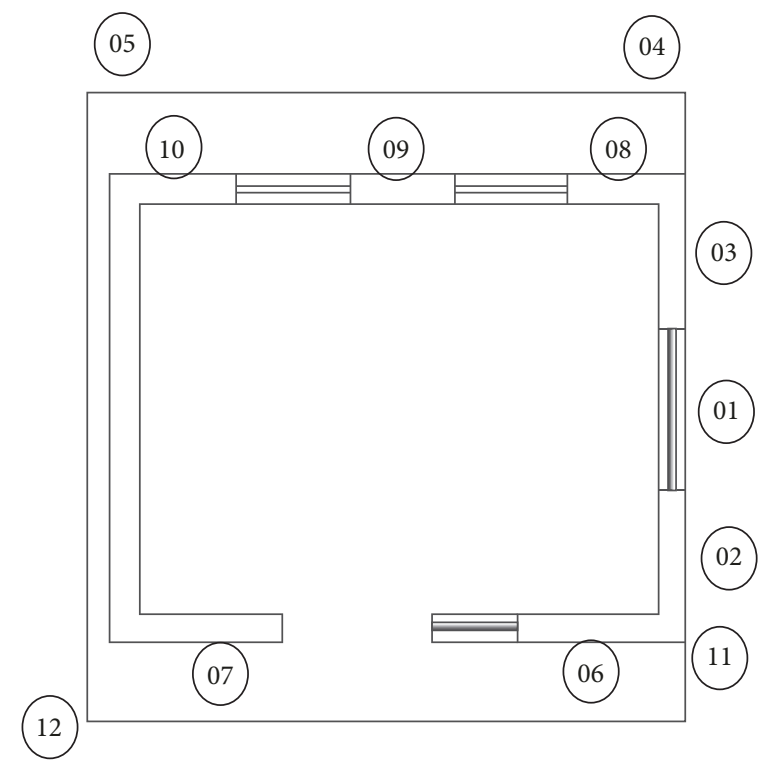

(a) Plan view

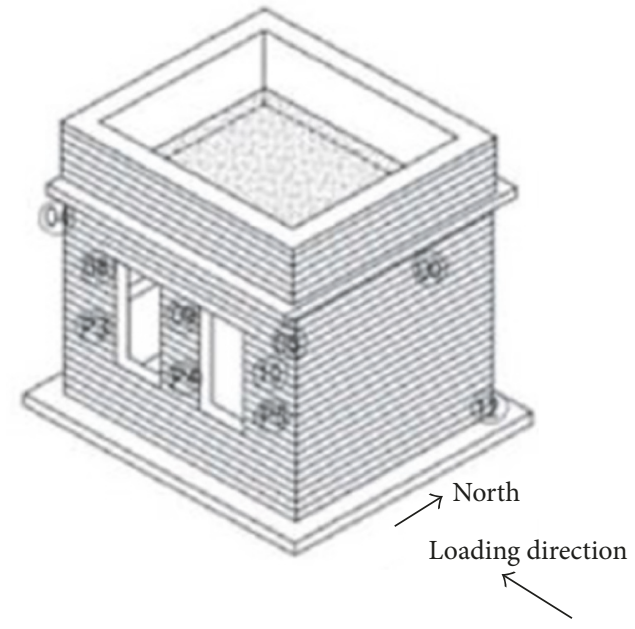

(b) Southeast view

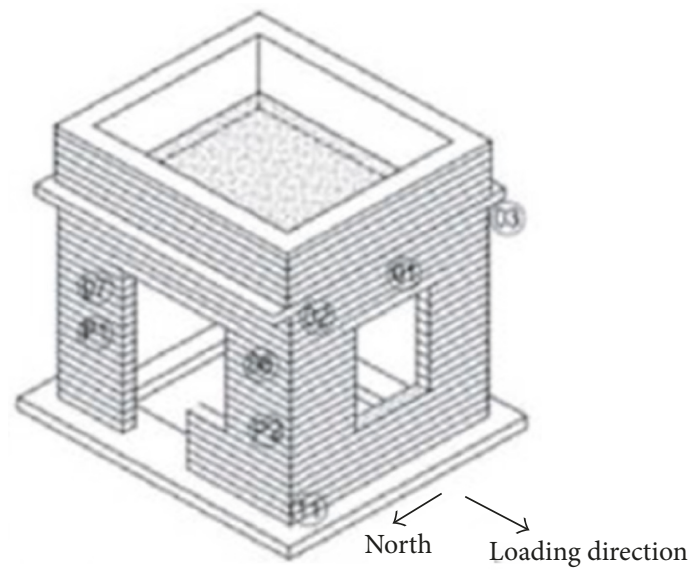

(c) Northwest view

FIGURE 4: Location of LVDTs on the full-scale building model.

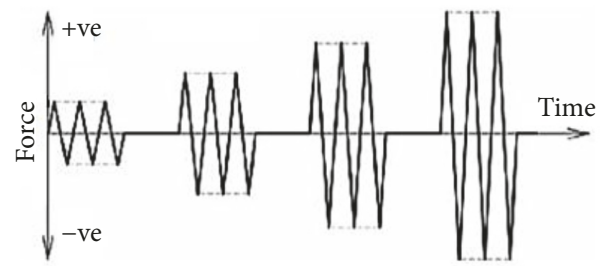

FIGURE 5: The pattern of quasistatic loading protocol.

according to the force controlled environment. The test was started from the lateral load of $58.9 \mathrm{kN}$ (6 tons) and it lasted at the load value of $258.96 \mathrm{kN}$ (26 Tons). The load was amplified with an increment of 2 tons in each successive cycle, which makes ten load cycles. During the first load cycle of $58.9 \mathrm{kN}$ (6 tons), corresponding to the story drift of $0.0018 \%$ no crack was observed. Under load cycles from $78.5 \mathrm{kN}$ ( 8 tons) to $137.3 \mathrm{kN}$ (14 tons) of force no cracks were seen. The earthquake force is always deterministic, so to simulate it with our testing facility the load was therefore increased from $137.3 \mathrm{kN}$ (14 tons) to $176.5 \mathrm{kN}$ (18 tons) so that the cracks may be observed. For better understanding, the data was plotted for drift cycles that were obtained for each corresponding load cycle. All the drift cycles are indicated in Table 2. The noise filter was applied to the raw data obtained from data acquisition system using a three- (3-) point moving average method. The filtered data was then used to plot the hysteresis curves and to determine other parameters such as the displacement ductility, response modification factor, and torsion effects as presented in the following sections. During each displacement cycle, structure was monitored carefully in addition to inspections between the cycles. The test was 
TABLE 1: Material properties.

\begin{tabular}{lcr}
\hline Symbol & Description & Value \\
\hline- & Water absorption of bricks (\%) & 24.37 \\
$f_{b}$ & Masonry unit compressive strength (MPa) & 14.40 \\
$f_{b t}$ & Modulus of rupture (MPa) & 3.38 \\
$f_{m^{\prime} o}$ & Compressive strength of mortar $(\mathrm{MPa})$ & 5.63 \\
$f_{m^{\prime}}$ & Compressive strength of masonry (MPa) \\
$E_{m}$ & Elastic modulus of masonry (MPa) & 3.51 \\
$f_{t u}$ & Diagonal tensile strength of masonry (MPa) \\
$C$ & Cohesion & 1227.0 \\
\hline
\end{tabular}

TABLE 2: Description of damage progression for the original building.

\begin{tabular}{lccc}
\hline Story drift (\%) & Damage description & Governing failure mode & Referenced figure \\
\hline 0.093 & $\begin{array}{c}\text { Diagonal hairline cracks at lintel level of } \\
\text { P1, P2, P3 \& P5 }\end{array}$ & Shear \\
0.16 & $\begin{array}{c}\text { Diagonal cracks passing through P1. At } \\
\text { P2 \& P5 diagonal cracks starting from the } \\
\text { base and ending at the window } \\
\text { Diagonal shear cracks at P1. Vertical } \\
\text { cracks in P5 }\end{array}$ & Rocking and vertical splitting & 6(a) \\
0.34 & $\begin{array}{c}\text { Scissor cracks over east wall } \\
0.65\end{array}$ & Shear and diagonal tension & C(b) \\
0.73 & Combination of vertical, horizontal, and \\
radial cracks at the eastward wall & Global/local rocking and shear & $6(\mathrm{c})$
\end{tabular}

stopped when sufficient cracking observed in the structure as shown in Figures 6-12.

\section{Observed Damage}

Figure 6 shows the crack patterns for the room model with increasing story drifts, and the qualitative summary for that is given in Table 2. During the first load cycle of $59.76 \mathrm{kN}$ (6 tons) corresponding to the story drift of $0.0018 \%$ no crack was observed which shows that the model was strong enough to resist the applied load robustly without any crack propagation. Under load cycles from 79.68 to $139.44 \mathrm{kN}$ ( 8 to 14 tons), no cracks were seen which shows the increased resistance of the brick masonry due to the confinement. Hence, it shows that confinement causes increase in the lateral load carrying capacity of the brick masonry building. The earthquake force is always indeterministic, so to simulate it with our testing facility the load was therefore been increased from 139.44 to $179.28 \mathrm{kN}$ (14 to 18 tons) so that the cracks may be observed. At a force of $179.28 \mathrm{kN}$ (18 tons) corresponding to a story drift of $0.093 \%$, Diagonal hair line cracks appeared in the lower left corner of pier 2 and started propagating towards the lintel beam. Similar diagonal crack appeared in the upper right corner of pier 1 and started propagating towards the toe of pier 1. During the reverse cycle, diagonal hairline cracks started appearing at the lower right corner of pier 2 and started propagating upward and vice versa for pier 1 . No crack appeared in pier 4 whereas diagonal cracks appeared in piers 3 and 5.

At a load of $199.2 \mathrm{kN}$ (20 tons) corresponding to a story drift of $0.16 \%$, hair line cracks appeared at the center of pier 2 above the sill level which started propagating towards the lintel beam thereby showing that the cracks are of shear nature that exceeded the tensile strength of masonry. Moreover, such cracks likely appeared in the center of pier 2 and extended towards the tie columns.

At a load of $219.12 \mathrm{kN}$ (22 tons) corresponding to a story drift of $0.34 \%$, the diagonal shear cracks become wider and propagate through the lintel beam in pier 2. Cracks also started appearing in the right toe of pier 1 during the positive cycle and propagated upward. Similarly, during the reverse cycle, scissor like cracks appeared in pier 1 . In the southern wall, the shear cracks also started appearing near the foundation pad and below the sill levels.

At a load of $258.96 \mathrm{kN}$ (26 tons) corresponding to a story drift of $0.73 \%$, both of the tie columns of the strong wall cracked at the middle because of flexure stresses. The cracks in pier 1 of the northern wall widened up to 3 inches, which makes it yielded showing the phenomenon of toe crushing. The diagonal shear cracks in pier 2 propagated through the slab such that the slab crumbled. The test was stopped and the crack pattern was then observed carefully. In Figures 7-12, stair stepped cracks and cracks passing through the solid bricks are seen at drift level of $0.73 \%$.

\section{Force-Deformation Behavior}

Figures 13 and 14 show the force-deformation response of the CBM building for hysteresis and envelope curves, respectively, obtained from gauges $06-10$. Story drift ratio defined as "the ratio of the lateral displacement of story to the height of story" is used here to indicate the lateral 
Crack patterns corresponding to 18 tons of load and story drift of $0.093 \%$

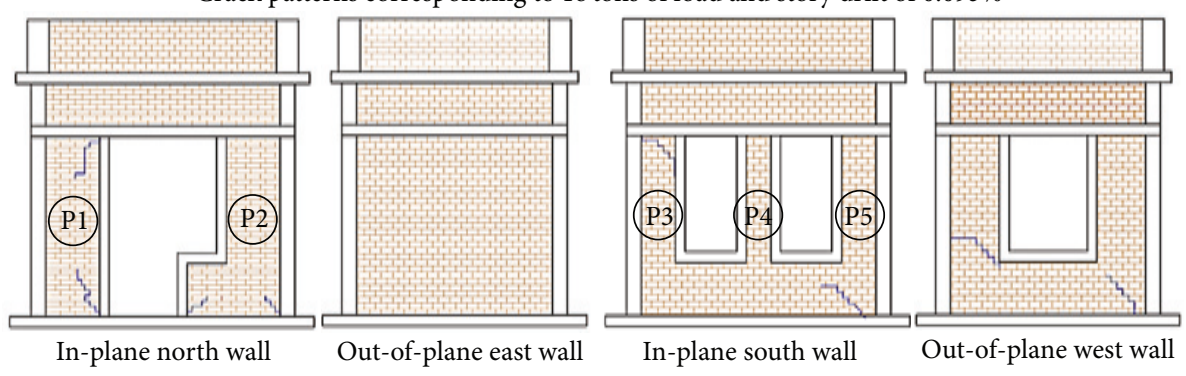

(a) At $0.093 \%$ story drift

Crack pattern corresponding to 20 tons of load and story drift of $0.16 \%$

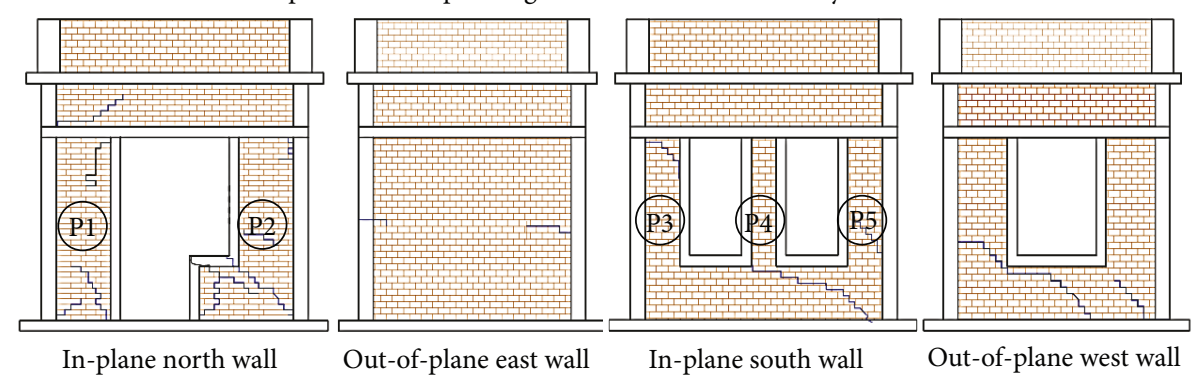

(b) At $0.16 \%$ story drift

Crack pattern corresponding to 22 tons of load and story drift of $0.34 \%$

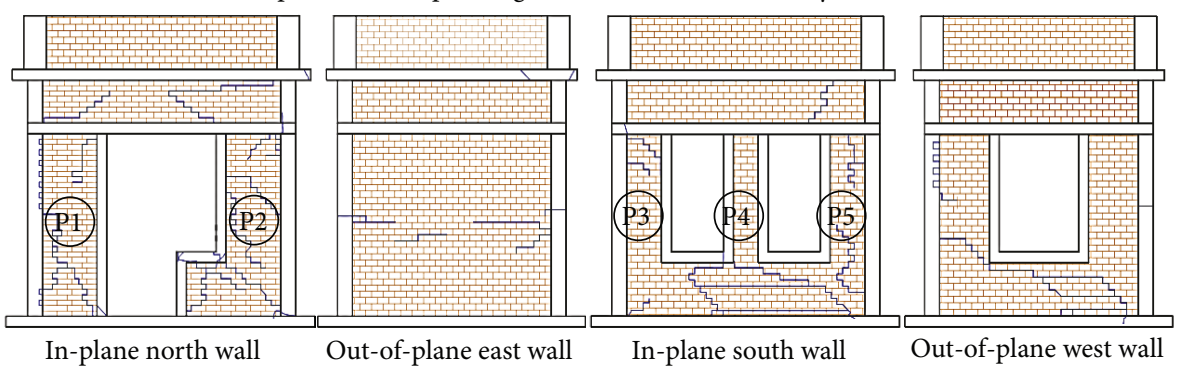

(c) At $0.34 \%$ story drift

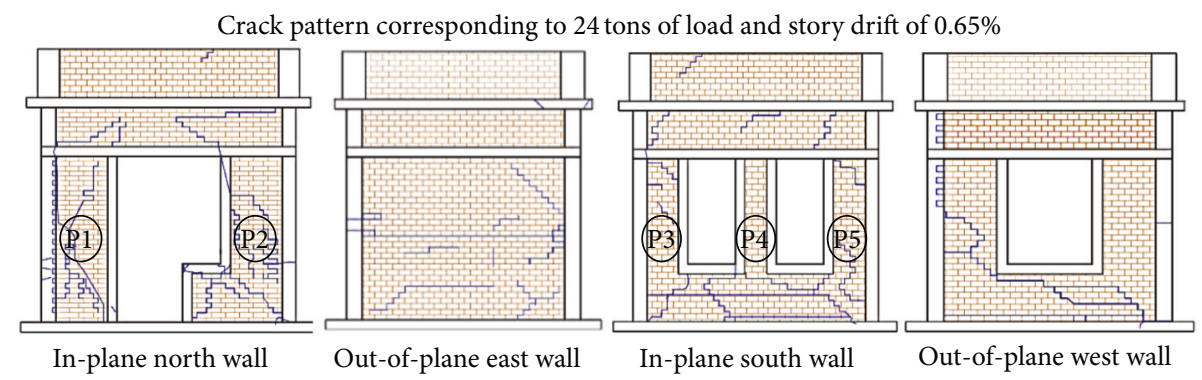

(d) At $0.65 \%$ story drift

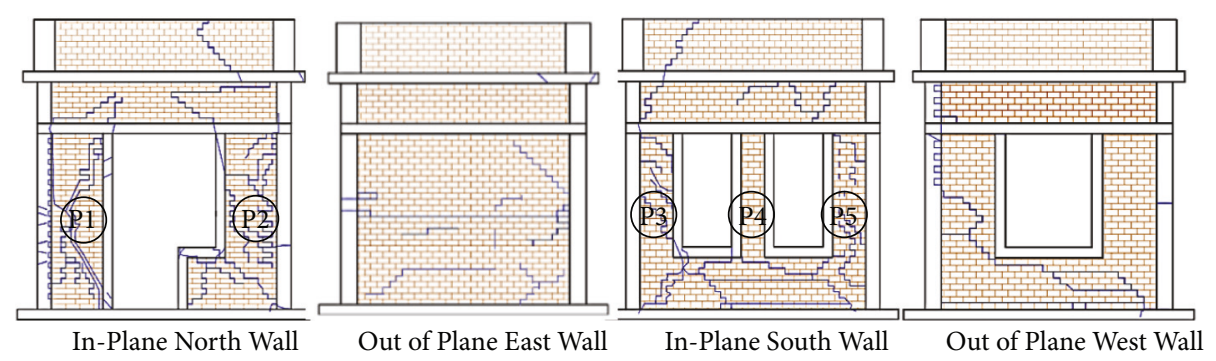

(e) At $0.73 \%$ story drift

FIGURE 6: Crack patterns at different drift levels for the intact building (note: P stands for pier). 


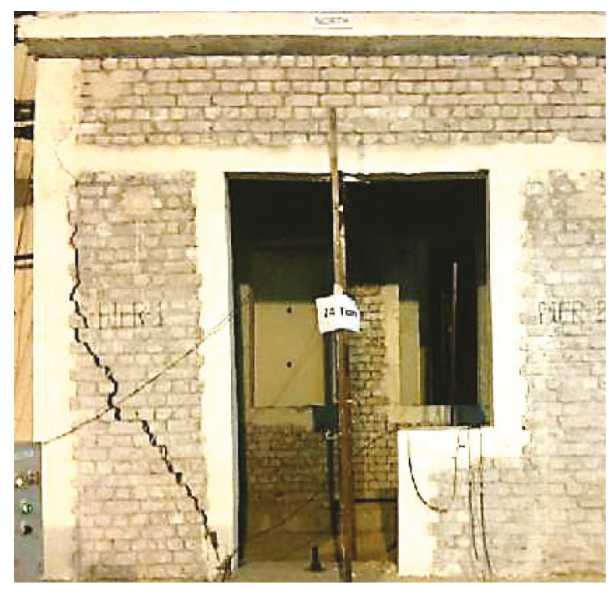

FIGURE 7: Diagonal shear cracks in pier 1 corresponding to story drift of $0.34 \%$.

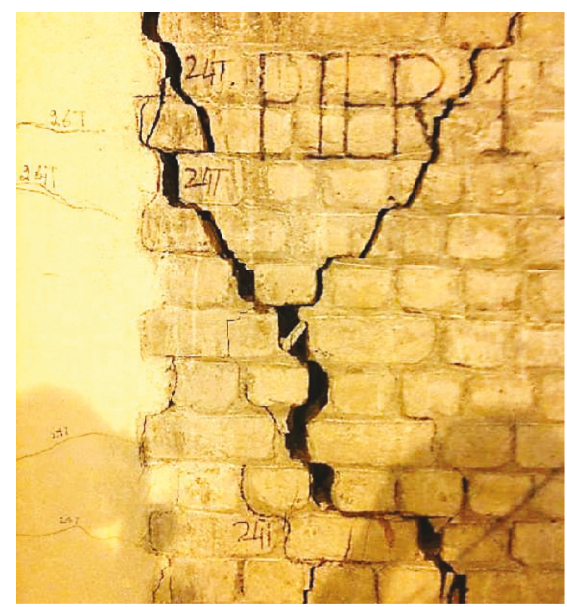

FIGURE 8: Diagonal shear cracks showing a scissor pattern corresponding to story drift of $0.73 \%$.

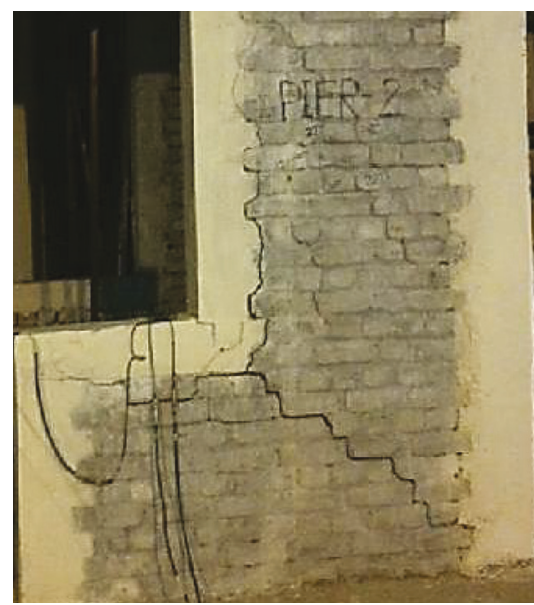

FIGURE 9: Diagonal shear cracks in pier 2 corresponding to story drift of $0.73 \%$.

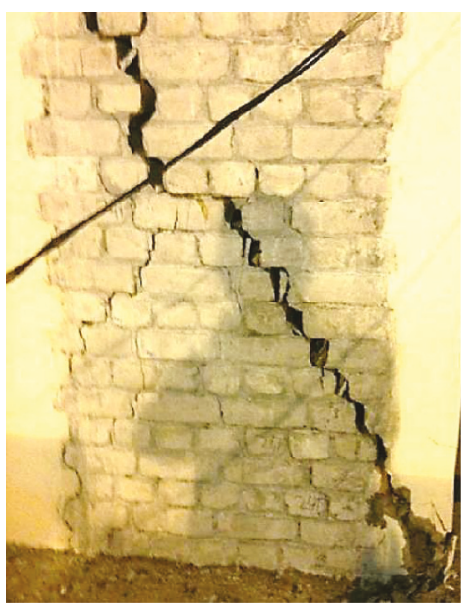

FIGURE 10: Cracking of toe in pier 1 corresponding to story drift of $0.73 \%$.

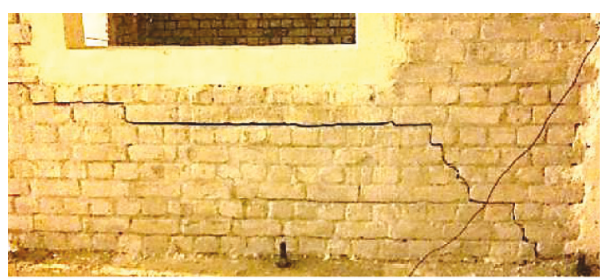

FIGURE 11: Combination of flexure and shear cracks in the out-ofplan wall corresponding to story drift of $0.65 \%$.

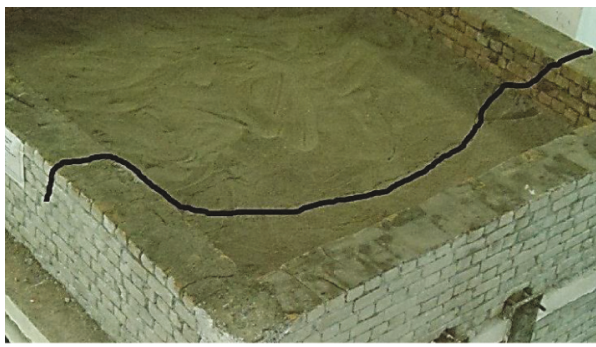

FIGURE 12: Line shows the crack appeared in the slab.

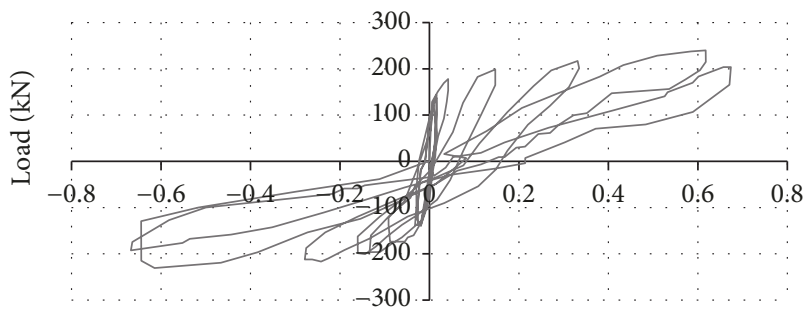

Story drift (\%)

Experimental

Figure 13: Hysteresis loop of CBM building. 


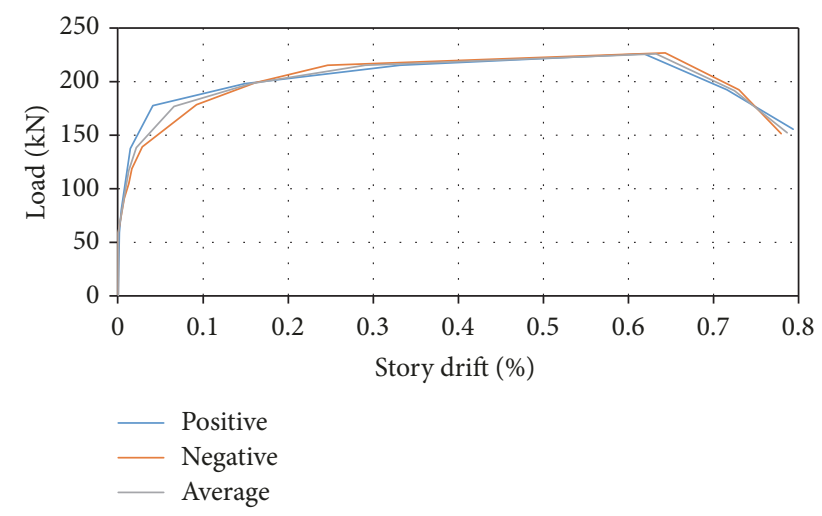

FIGURE 14: Envelop curves for CBM building.

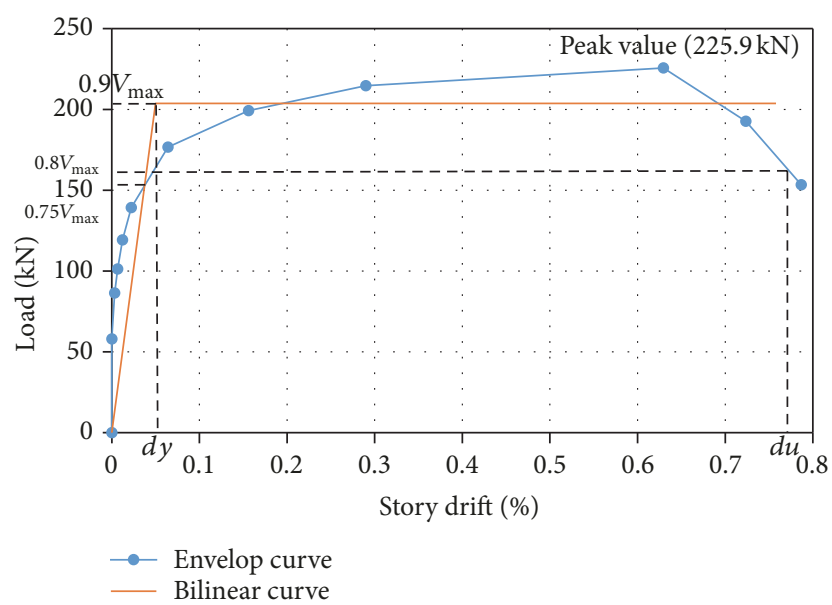

FIGURE 15: Bilinear curve of CBM building.

deformation. As a sign convention, the push direction was taken as positive and vice versa. Envelop curves are drawn by joining the points of maximum positive and negative loads in each cycle. Tangent stiffness decreases with increasing displacements and became very small at $0.20 \%$ story drift. The structure reached its maximum resistance at $0.65 \%$ story drift, after which the strength degradation initiated at a slow pace. The gradual degradation of the structure began beyond the story drift of $0.65 \%$ of peak resistance. The test was stopped when the resistance decreased to $89 \%$ of the maximum loading corresponding to $0.70 \%$ story drift $(200.7 \mathrm{kN})$.

An idealized bilinear curve was made by the average of the force-deformation envelope curves in both the positive and negative directions. Based on equal energy principle, a method proposed by Magenes and Calvi [18] was used to develop an elastoplastic curve. From the average backbone curve shown in Figure 15, the maximum load, $V_{u}$, was approximated as $V_{u}=0.9 \mathrm{Vmax}$. The effective stiffness, $K_{\text {eff }}$, was taken as the ratio of $0.75 V_{u}$ to the corresponding displacement in the envelope curve. The yield displacement was then calculated as $\Delta_{y}=V_{u} / K_{\text {eff. }}$. The ultimate displacement was taken at a point corresponding to $0.8 V_{u}$ in the envelope curve. The displacement ductility denoted by $\mu_{D}$ was then

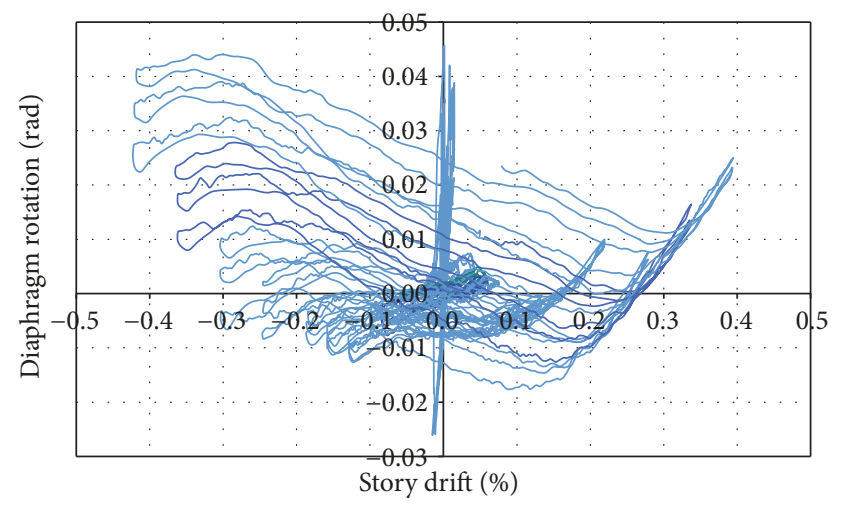

FIGURE 16: Effect of torsion produced in the form of diaphragm rotation in nonretrofitted block masonry building.

found as the ratio of the ultimate to the yield displacement; that is,

$$
\mu_{D}=\frac{\Delta_{u}}{\Delta_{y}}
$$

From Figure 15, the ultimate and yield story drifts for the room model were found to be $0.772 \%$ and $0.051 \%$, respectively. The displacement ductility is thus found as $0.772 / 0.051$ $=15.13$. Response modification factor, $R$, which can be defined as one of the seismic design parameters to consider nonlinear performance of building structures during strong earthquake and relying on this, many seismic design codes led to reduce loads. Similarly, for seismic design, it is important to estimate, maximum lateral displacement of structures due to sever earthquakes for several reasons. Seismic design provisions estimate the maximum roof and story drifts occurring in major earthquakes by amplifying the drifts obtained by elastic analysis with a displacement amplification factor $C_{d}$. Both the parameters are obtained from the following relations:

$$
\begin{aligned}
R & =\sqrt{2 \mu_{D}-1} \\
C_{d} & =\frac{\mu_{D}}{\sqrt{2 \mu_{D}-1}} .
\end{aligned}
$$

Using (2), one finds the values of $R$ and $C_{d}$ as 5.41 and 2.79, for the original building.

As mentioned earlier, the model building was fabricated to represent a typical masonry construction in northern areas of Pakistan. A comparison of the study can, therefore, be made with other studies, which investigated a similar type of construction. In this context, the results of the room model presented in this study are compared to sour (4) other studies. Comparison is made to those of Shahzada et al. [15], who studied a similar building configuration, which, however, was made of unconfined and unreinforced brick masonry. Similarly, for the same retrofitted building, the results are compared to those of Ashraf [16], who studied the retrofitting of the same unconfined brick masonry building. Another comparison was made for the building tested before and after retrofitting, by Zeeshan et al. [17], who studied a similar building configuration, which, however, was made of 
TABLE 3: Change in force deformation parameters and comparison with results of Shahzada et al. [15], Ashraf [16], and Zeeshan et al. [17].

\begin{tabular}{lccccc}
\hline $\begin{array}{l}\text { Force deformation } \\
\text { parameters }\end{array}$ & $\begin{array}{c}\text { Unreinforced brick } \\
\text { masonry [15] }\end{array}$ & $\begin{array}{c}\text { URCBM before } \\
\text { retrofitting [17] }\end{array}$ & $\begin{array}{c}\text { Unreinforced brick } \\
\text { masonry after } \\
\text { retrofitting [16] }\end{array}$ & $\begin{array}{c}\text { URCBM after } \\
\text { retrofitting [17] }\end{array}$ & $\begin{array}{c}\text { Confined brick } \\
\text { masonry }\end{array}$ \\
\hline $\begin{array}{l}\text { Lateral stiffness } \\
(\mathrm{KN} / \mathrm{mm})\end{array}$ & 73.8 & 62.8 & 168.9 & 154.11 & 122.02 \\
$\begin{array}{l}\text { Lateral strength } \\
(\mathrm{kN})\end{array}$ & 106.3 & 106.8 & 220.3 & 219.96 & 258.96 \\
Ultimate drift (\%) & 0.5 & 0.55 & 0.37 & 0.37 & 0.73 \\
\hline
\end{tabular}

concrete block masonry rather than brick masonry. Table 3 compares the stiffness, strength, and ultimate drift obtained of these four (4) studies with ours.

\section{Torsional Effects}

To avoid any torsion in the building, an attempt was made in design of model to keep the lateral stiffness of both in-plane walls the same. However, two out-of-plane gauges (numbers 04 and 05) were installed, to record any possible torsion. The diaphragm rotation was measured as the sum of the displacement recorded by these two gauges divided by the distance between them. The rotation as a function of story drift is shown in Figure 16. The maximum rotation was 0.0044 for the CBM building. Positive direction rotation was smaller than the negative direction. We see that the symmetrical conception of rigidity has succeeded. However, the increasing levels of asymmetry were associated with the increasing level of damage (due to unequal loss of rigidity in the walls), which resulted in torsional effects.

\section{Summary and Conclusions}

The following conclusions are made based on the experiments and ensuing calculations.

(1) The test results reveal that the confined brick masonry is more robust and ductile against the seismic forces because of the confining elements that hold the whole model to act as single mass unit.

(2) Confinement of the brick masonry is an effective technique in improving the seismic performance of unreinforced brick masonry structures.

(3) By confinement, the brick masonry of the lateral strength of the model structure is doubled in this research study as compared to the unconfined brick masonry tested by Shahzada et al.

(4) The cost of the confined brick masonry construction is $50 \%$ more than that of the unconfined brick masonry construction in this research studies.

(5) The effective stiffness, $K_{\text {eff }}$, for the CBM building is $122.03 \mathrm{kN} / \mathrm{mm}$ which is $65 \%$ more than unconfined brick masonry $(73.8 \mathrm{kN} / \mathrm{mm})$ and $94.3 \%$ more than unconfined concrete block masonry $(62.8 \mathrm{kN} / \mathrm{mm})$.

(6) The lateral load capacity of the CBM structure is $258.96 \mathrm{kN}$ which was more than all of the unconfined brick masonry and concrete block masonry before and after the retrofitting.

(7) Displacement ductility, $\mu_{D}$, response modification factor, $R$, and displacement amplification factor, $C_{d}$, were calculated from the idealized bilinear curves for CBM building. The values of $\mu_{D}, R$, and $C_{d}$ were obtained as $15.31,5.41$, and 2.79 , respectively. These values are recommended for consideration in development of seismic design guidelines.

However, it should be noted that above-mentioned findings and conclusions cannot be generalized and hence refer to only one experimental test.

\section{Disclosure}

The experimental work presented in this paper was a part of project "Seismic Capacity Assessment of Confined Brick Masonry Building” by Directorate of Science \& Technology.

\section{Conflicts of Interest}

The authors declare that there are no conflicts of interest regarding the publication of this paper.

\section{Acknowledgments}

The authors are grateful to the Directorate of Science \& Technology, Government of Khyber Pakhtunkhwa, for providing the financial support.

\section{References}

[1] M. Tomazevic, Earthquake-Resistant Design of Masonry Buildings, Imperial College Press, London, UK, 1999.

[2] D. Anderson and S. Brzev, "Seismic Design Guide for Masonry Buildings," 2009.

[3] S. Brzev, Earthquake-Resistant Confined Masonry Construction, National Information Center of Earthquake Engineering, Indian Institute of Technology Kanpur, 2008.

[4] K. Yoshimura, K. Kikuchi, M. Kuroki et al., "Experimental study for developing higher seismic performance of brick masonry walls," in Proceedings of the 13th World conference on earthquake engineering, Vancouver, Canada, 2004.

[5] B. Calderoni, P. Lenza, and P. P. Rossi, "Pushover tests on intermediate-scale model of masonry buildings with rigid floor," The Masonry Society Journal, vol. 22, no. 1, pp. 71-85, 2004 . 
[6] G. S. Epperson and D. P. Abrams, "Nondestructive evaluation of masonry buildings," Tech. Rep. 89-26-0389-26-03, College of Engineering, University of Illinois at Urbana-Champaign, Advanced Construction Technology Center, Urbana, Ill, USA, 1989.

[7] D. P. Abrams and N. Shah, "Cyclic load testing of unreinforced masonry walls," Advanced Construction Technology Center 92-26-10, College of Engineering, and University of Illinois at Urbana-Champaign, Advanced Construction Technology Center, and Urbana, 1992.

[8] G. Magenes and G. M. Calvi, "Cyclic behavior of brick masonry walls," in Proceedings of the 10th World Conf. on Earthquake Engineering, pp. 3517-3522, Madrid, Spain, 1992.

[9] A. Anthoine, G. Magonette, and G. Magenes, "Shear compression testing and analysis of brick masonry walls," in Proceedings of the 10th European Conf. on Earthquake Engineering, Taylor and Francis, pp. 1657-1662, Taylor and Francis, Rotterdam, The Netherlands, 1995.

[10] T. Manzouri, P. B. Shing, B. Amadei, M. Schuller, and R. Atkinson, "Repair and retrofit of unreinforced masonry walls: experimental evaluation and finite element analysis," Tech. Rep. CU/SR-95/2, Dept. of Civil, Environmental, and Architectural Engineering, University of Colorado, Boulder, Colo, USA, 1995.

[11] M. Tomaževič, M. Lutman, and L. Petković, "Seismic behavior of masonry walls: Experimental simulation," Journal of Structural Engineering, vol. 122, no. 9, pp. 1040-1047, 1996.

[12] J. Craig, B. Goodno, P. Towashiraporn, and J. Park, "Fragility reduction estimations for URM buildings using response modification," in Proceedings of the 12th European Conf. on Earthquake Engineering Research, London, UK, 2002.

[13] S. Franklin, J. Lynch, and D. P. Abrams, Performance of rehabilitated URM shear walls: flexural behavior of piers," (CDROM) Mid-America Earthquake Center, University of Illinois at Urbana-Champaign, Urbana, Ill, USA, 2003.

[14] C. Simsir, M. Aschheim, and D. Abrams, "Influence of diaphragm flexibility on the outof- plane response of unreinforced masonry bearing walls," in Proceedings of the 9th North American Masonry Conference (CD-ROM), Clemson, 2002.

[15] K. Shahzada, A. N. Khan, A. S. Elnashai et al., "Experimental seismic performance evaluation of unreinforced brick masonry buildings," Earthquake Spectra, vol. 28, no. 3, pp. 1269-1290, 2012.

[16] M. Ashraf, Development of Cost-effective and Efficient Retrofitting Technique for Masonry Buildings in Pakistan [Ph.D. thesis], Department of Civil Engineering, UET, Peshawar, Pakistan, 2010.

[17] A. Zeeshan, S. Khan, C. Bora et al., "Seismic capacity assessment of unreinforced concrete block masonry buildings in pakistan before and after retrofitting," Journal of Earthquake Engineering, vol. 19, no. 3, pp. 357-382, 2015.

[18] G. Magenes and G. M. Calvi, "In-plane seismic response of brick masonry walls," Earthquake Engineering and Structural Dynamics, vol. 26, no. 11, pp. 1091-1112, 1997. 


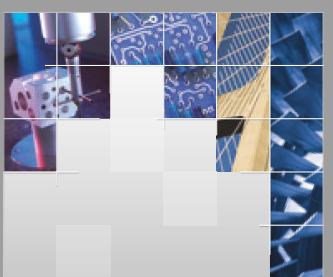

\section{Enfincering}
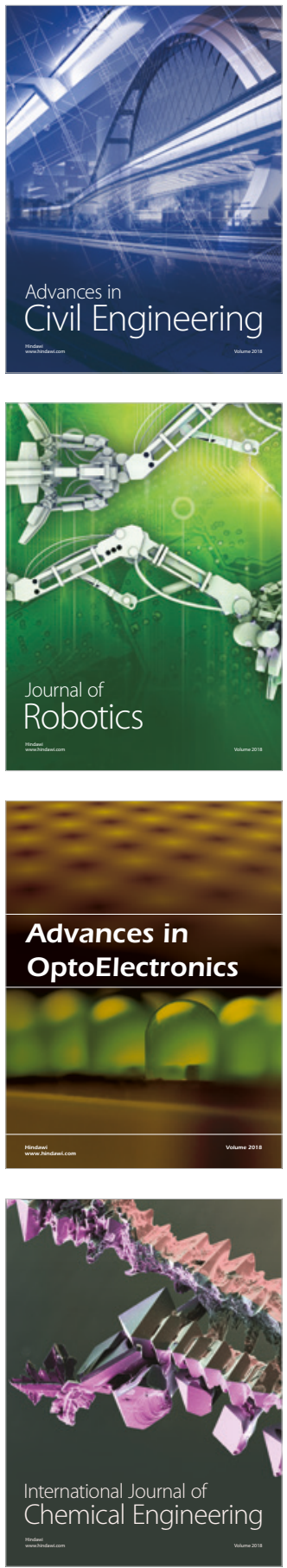

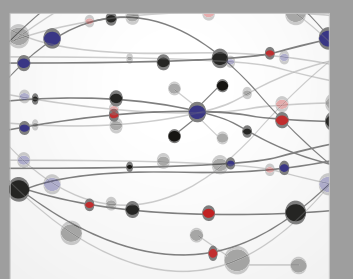

\section{Rotating \\ Machinery}

The Scientific World Journal

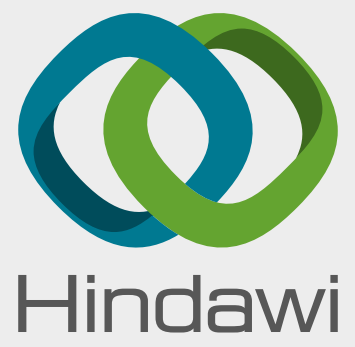

Submit your manuscripts at

www.hindawi.com
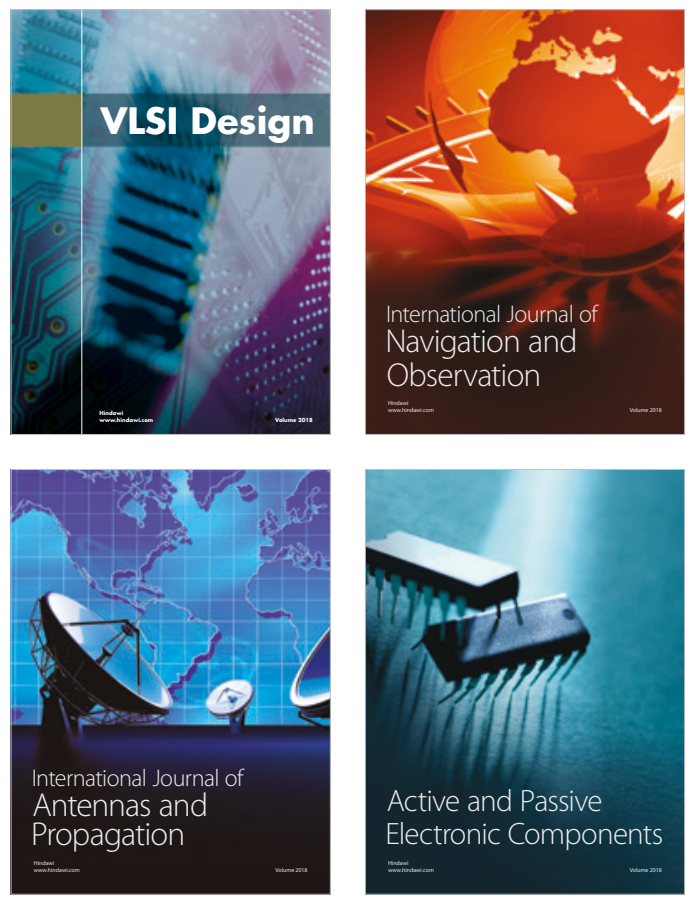
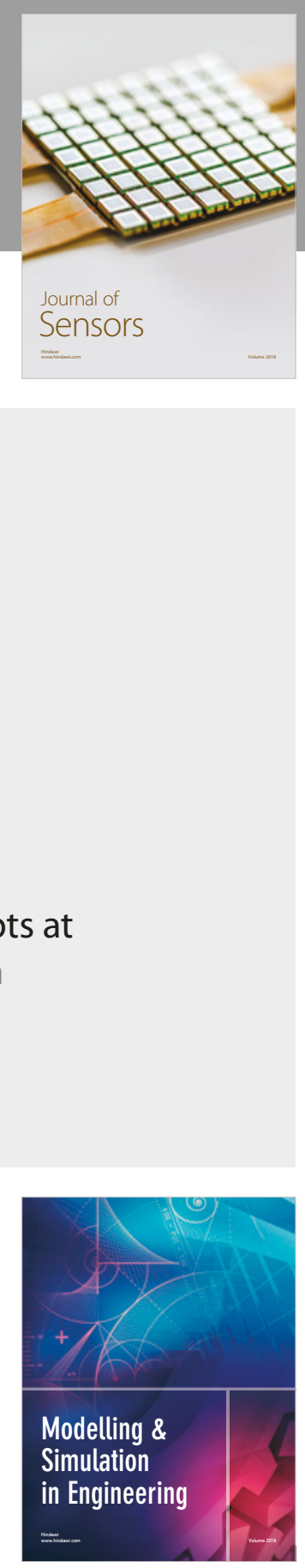

\section{Advances \\ Multimedia}
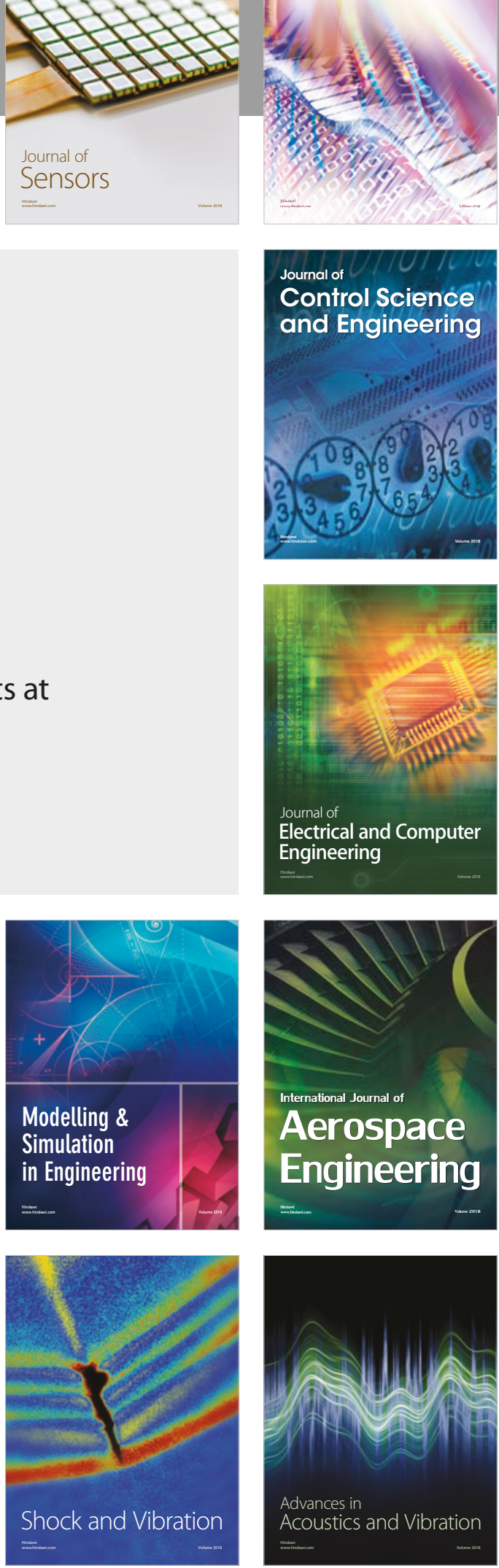